\title{
Mycoplasma pneumoniae infection and neurological disease
}

N H Thomas, J E Collins, S A Robb, R O Robinson

\begin{abstract}
The cases are reported of 13 children seen over a 22 month period who presented with a variety of acute neurological illnesses associated with Mycoplasma pneumoniae infection. Although presentation with a decreased level of consciousness or seizures was common, psychosis, hemiparesis, cranial nerve palsies, and Guillain-Barré syndrome were also seen. In contrast with published reports, only one child had an associated chest infection. Although some children have been left with residual disability, most have made a complete recovery. In this recent experience, $M$ pneumoniae is a not rare cause of neurological illness in childhood and may present in unusual ways.
\end{abstract}

(Arch Dis Child 1993; 69: 573-576)

Neurological illness associated with $\mathrm{Myco}$ plasma pneumoniae has been previously described, but its importance as an infective cause of acute neurological symptoms in childhood has been minimised in reviews of the subject. ${ }^{1}$ Our recent experience suggests that the incidence of neurological disease associated with $M$ pneumoniae in childhood is more common than previously recognised. We report here 13 patients who presented in a variety of ways.

\section{Patients}

Six boys and seven girls presented between June 1990 and May 1992. Ages ranged from $2 \cdot 8$ years to 15.3 years (mean age 8.3 years). All had been resident in the United Kingdom for at least six months before becoming ill. Diagnosis was confirmed either by a fourfold change in the titre of complement fixing antibodies to $M$ pneumoniae, or by a high titre of IgM antibody to $M$ pneumoniae.

\section{CLINICAL FEATURES}

Table 1 summarises the clinical details of the patients.

\section{ALTERED CONSCIOUSNESS}

An encephalitic or meningoencephalitic presentation was common, occurring in 10 patients; the degree of altered consciousness varied widely. Four children had a Glasgow coma scale score of 14 on admission; however, five had a score of seven or less. Only two of

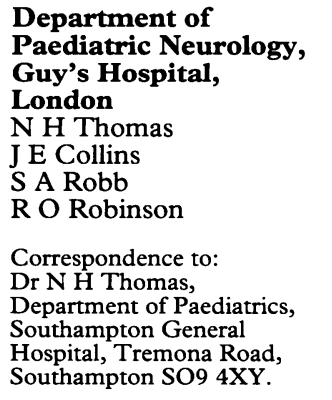

Accepted 3 August 1993

Table 1 Clinical features of patients

\begin{tabular}{|c|c|c|c|c|c|c|}
\hline $\begin{array}{l}\text { Patient } \\
\text { No }\end{array}$ & $\begin{array}{l}\text { Age at } \\
\text { presentation } \\
\text { (years) }\end{array}$ & $\operatorname{Sex}$ & $\begin{array}{l}\text { Clinical } \\
\text { presentation }\end{array}$ & $\begin{array}{l}\text { Respiratory } \\
\text { symptoms } \\
\text { or signs }\end{array}$ & Treatment & Outcome \\
\hline 1 & $13 \cdot 4$ & $\mathrm{~F}$ & $\begin{array}{l}\text { Encephalitis, cranial nerve } \\
\text { palsies, hemiplegia }\end{array}$ & None & $\begin{array}{l}\text { Erythromycin, } \\
\text { corticosteroids }\end{array}$ & $\begin{array}{l}\text { Incomplete } \\
\text { recovery, mild } \\
\text { residual signs }\end{array}$ \\
\hline 2 & $13 \cdot 8$ & M & $\begin{array}{l}\text { Encephalitis, seizures, con- } \\
\text { fusion }\end{array}$ & $\begin{array}{l}\text { Cough, sore } \\
\text { throat }\end{array}$ & Erythromycin & Complete recovery \\
\hline 3 & $5 \cdot 0$ & $\mathrm{~F}$ & Encephalitis, seizure & Cough & $\begin{array}{l}\text { Erythromycin, } \\
\text { corticosteroids, } \\
\text { acyclovir, venti- } \\
\text { lated }\end{array}$ & $\begin{array}{l}\text { Severe handicap, } \\
\text { intellectual } \\
\text { impairment, spas- } \\
\text { tic quadriplegia }\end{array}$ \\
\hline 4 & $10 \cdot 3$ & $\mathbf{M}$ & Meningoencephalitis & None & None & $\begin{array}{l}\text { Occipital headaches, } \\
\text { short term } \\
\text { memory loss }\end{array}$ \\
\hline 5 & $6 \cdot 6$ & $\mathrm{~F}$ & $\begin{array}{l}\text { Seizures, encephalitis, sub- } \\
\text { sequent extrapyramidal } \\
\text { syndrome }\end{array}$ & None & $\begin{array}{l}\text { Acyclovir, anticon- } \\
\text { vulsants }\end{array}$ & $\begin{array}{l}\text { Motor disorder, } \\
\text { intellectual } \\
\text { impairment }\end{array}$ \\
\hline 6 & $12 \cdot 4$ & $\mathbf{F}$ & Psychosis, seizures & None & None & $\begin{array}{l}\text { Short term memory } \\
\text { poor }\end{array}$ \\
\hline 7 & $3 \cdot 4$ & $\mathbf{M}$ & Seizures & None & $\begin{array}{l}\text { Acyclovir, ery- } \\
\text { thromycin, anti- } \\
\text { convulsants }\end{array}$ & Complete recovery \\
\hline 8 & $5 \cdot 7$ & $\mathbf{F}$ & Meningoencephalitis & Cough & $\begin{array}{l}\text { Cefotaxime, acy- } \\
\text { clovir, ery- } \\
\text { thromycin }\end{array}$ & Complete recovery \\
\hline 9 & $2 \cdot 3$ & $\mathrm{~F}$ & Encephalitis & None & $\begin{array}{l}\text { Cefotaxime, acy- } \\
\text { clovir, ery- } \\
\text { thromycin, } \\
\text { ventilated }\end{array}$ & Complete recovery \\
\hline 10 & $8 \cdot 5$ & $\mathbf{M}$ & Guillain-Barré & None & None & Complete recovery \\
\hline 11 & $10 \cdot 0$ & F & $\begin{array}{l}\text { Encephalitis, convulsions, } \\
\text { psychosis }\end{array}$ & None & Erythromycin & $\begin{array}{l}\text { Intellectual impair- } \\
\text { ment }\end{array}$ \\
\hline 12 & $2 \cdot 3$ & $\mathbf{M}$ & $\begin{array}{l}\text { Encephalitis, right sided } \\
\text { signs }\end{array}$ & None & Erythromycin & Complete recovery \\
\hline 13 & $15 \cdot 3$ & $\mathbf{M}$ & $\begin{array}{l}\text { Guillain-Barré, menin- } \\
\text { goencephalitis }\end{array}$ & None & None & Slow recovery \\
\hline
\end{tabular}


these patients required ventilation; in both patients this was for respiratory support due to inadequate respiratory effort rather than for management of cerebral oedema.

\section{SEIZURES}

Six children had generalised seizures in the course of their illness, with three presenting with this symptom. Seizures were successfully controlled with intravenous phenytoin in all but one patient, in whom intravenous chlormethiazole was necessary. Electroencephalography in three patients showed generalised slow wave activity compatible with encephalitis; one was normal. One child, patient 5 , had right sided focal seizures as well as generalised seizures. This patient had three further electroencephalograms taken, which initially showed bursts of sharp and slow wave activity and evolved into a low voltage record with no paroxysmal features over the following four months.

\section{PSYCHOSIS}

Three patients developed marked behavioural symptoms in their illness, two of which were florid and bizarre. Patient 6 started talking in an American accent, mimicking her favourite pop group. She also appeared to experience visual hallucinations. In patient 11 , the initial encephalitic illness was characterised by visual hallucinations as well as disinhibited sexual statements, which led to initial child protection inquiries.

\section{GUILLAIN-BARRÉ SYNDROME}

Two children had postinfectious demyelinating polyneuropathy. One presented with gradual onset areflexic quadriparesis after a mild throat infection, whereas the other presented a more complicated picture, developing a meningoencephalitis first before proceeding to develop areflexia and weakness. In these two children the diagnosis was supported by the electrophysiological findings.
FOCAL NEUROLOGY

Three patients had focal neurological signs as part of their illness. In patient 1 , the onset of left facial weakness and left hemiparesis was abrupt and recovery slow. Brain imaging was normal. In patient 5, recovery was characterised by a marked extrapyramidal syndrome with a festinant gait. Patient 12 presented with tremor and unsteadiness on the right side.

\section{CHEST SYMPTOMS}

In 10 patients there was no antecedent respiratory illness either in clinical or radiological terms. In the remaining three, in only one was there definite evidence of lower respiratory tract illness. The remaining two patients developed mild respiratory tract symptoms before the onset of their neurological illness.

Table 2 summaries laboratory details of the patients.

\section{INVESTIGATIONS}

The diagnosis of $M$ pneumoniae infection was based on a fourfold change in complement fixing IgG antibodies to $M$ pneumoniae, or a positive test for IgM antibodies; in only one patient were we entirely reliant on the identification of IgM antibodies alone. In a number of patients the decrease in IgG titres reflected the timing of the samples in the illness. We did not seek to identify cold agglutinins routinely; they were present in patient 2 .

Cerebrospinal fluid findings were not significant. The protein concentration was increased in only two of 12 samples (one Guillain-Barré syndrome). When white blood cell counts were increased (four of 12 samples), these were either polymorphs or lymphocytes, or a mixture of the two.

Chest radiographs were normal in four patients; in one there was left mid zone consolidation.

Computed tomography was performed in 11 patients and was reported as normal in 10 . In patient 3, with the worst outcome, the initial

Table 2 Investigations carried out

\begin{tabular}{|c|c|c|c|c|c|c|c|}
\hline \multirow{3}{*}{$\begin{array}{l}\text { Patient } \\
\text { No }\end{array}$} & \multicolumn{2}{|l|}{ Serology } & \multicolumn{2}{|l|}{ Cerebrospinal fluid } & \multirow{3}{*}{$\begin{array}{l}\text { Computed } \\
\text { tomogram }\end{array}$} & \multirow{3}{*}{$\begin{array}{l}\text { Magnetic } \\
\text { resonance scan }\end{array}$} & \multirow{3}{*}{$\begin{array}{l}\text { Chest } \\
\text { radiograph }\end{array}$} \\
\hline & I & 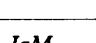 & \multirow{2}{*}{$\begin{array}{l}\text { White } \\
\text { cell count }(/ \mu l)\end{array}$} & \multirow{2}{*}{$\begin{array}{l}\text { Protein } \\
(g /)\end{array}$} & & & \\
\hline & $\operatorname{IgG} C F T^{\star}$ & $\operatorname{Ig} M$ & & & & & \\
\hline 1 & 40,160 & ND & 110 & 0.33 & Normal & Normal & ND \\
\hline 2 & $320,320,160$ & ND & 0 & $0 \cdot 19$ & Normal & ND & $\begin{array}{l}\text { Left mid zone } \\
\text { shadow }\end{array}$ \\
\hline 3 & 160,10 & ND & 0 & $0 \cdot 20$ & $\begin{array}{l}\text { Low density in } \\
\text { thalami and } \\
\text { periventricular } \\
\text { regions }\end{array}$ & ND & Normal \\
\hline 4 & 640,1280 & ND & 314 (bloodstained) & 0.30 & Normal & ND & Normal \\
\hline 5 & 320 & 40 & 15 & $0 \cdot 29$ & Normal & Normal & Normal \\
\hline 6 & ND & Positive & 0 & 0.25 & Normal & ND & ND \\
\hline 7 & 160,10 & ND & 0 & $0 \cdot 11$ & Normal & ND & ND \\
\hline 8 & 320,40 & ND & 22 & $0 \cdot 26$ & Normal & ND & ND \\
\hline 9 & 160,40 & ND & 45 & 1.50 & Normal & $\begin{array}{l}\text { Extensive white } \\
\text { matter change }\end{array}$ & ND \\
\hline 10 & 80,320 & ND & 0 & 1.48 & ND & ND & ND \\
\hline 11 & $<10,80$ & 160 & 4 & $0 \cdot 22$ & Normal & Normal & Normal \\
\hline 12 & $80,<10$ & ND & 2 & $0 \cdot 15$ & Normal & $\begin{array}{l}\text { Altered signal in } \\
\text { deep white }\end{array}$ & ND \\
\hline 13 & $80,<10$ & ND & ND & ND & ND & $\begin{array}{l}\text { matter } \\
\text { (Cord) Altered }\end{array}$ & ND \\
\hline 13 & $00,<10$ & NVD & ND & IVD & N & $\begin{array}{l}\text { signal over mid } \\
\text { dorsal cord }\end{array}$ & \\
\hline
\end{tabular}


computed tomogram showed low densities in the thalamic and periventricular regions; a subsequent scan three weeks later showed cerebral atrophy with widespread low densities within the cerebral parenchyma.

Magnetic resonance scanning of the brain was normal in three of the five scans performed. In the other two, both of whom had normal computed tomograms, there was an altered signal throughout the deep white matter. Patient 13 had a magnetic resonance scan of the spine; this was shown to have an area of altered signal over the mid dorsal cord, a finding of uncertain significance in the clinical setting.

\section{TREATMENT}

Eight patients received a course of erythromycin which lasted between 10 and 14 days. Those not treated in this way were not diagnosed until later in their illness. Two patients received corticosteroids in an attempt to accelerate recovery; in patient 1 there was a slow but incomplete recovery, but in patient 3 the severe residual spastic quadriplegia suggests that this treatment was ineffective.

\section{OUTCOME}

The two patients with Guillain-Barré syndrome have shown a steady recovery and neither has been left with major sequelae. In general, the 10 patients who presented with altered consciousness have shown considerable recovery; four have completely recovered, with a further three showing minor cognitive symptoms such as short term memory impairment.

Three patients have been left with major neurological sequelae from their illness: patient 3 has been left with a marked spastic quadriplegia and intellectual impairment; a computed tomogram only three weeks into the illness had shown marked cerebral atrophy with widespread low attenuation in the cerebral substance. Patient 5 has been left with intellectual impairment and is currently functioning at about one year less than her chronological age. Patient 11 has also shown intellectual impairment and a mixed expressive/receptive dysplasia which is slowly improving.

\section{Discussion}

Mycoplasmas are the smallest free living micro-organisms. They do not have a cell wall and are thus resistant to penicillins and cephalosporins. Mycoplasma pneumoniae is a major species pathogenic to humans and in some studies has been reported as the most common cause of lower respiratory tract infection in young adults and children. ${ }^{2} 3$

The epidemiology of $M$ pneumoniae infection is of interest as most of the patients reported here presented during the peak incidence of the four year epidemic cycle which mycoplasma infection runs. For example, laboratory notifications of $M$ pneumoniae infection to the Communicable Disease Surveillance Centre in 1990 totalled $1410,{ }^{4}$ whereas in
1991 , the peak year of the epidemic, this figure was $3179 .^{5}$

Neurological disease associated with $M$ pneumoniae is well described ${ }^{6-9}$ and most reports describe encephalitis, meningoencephalitis, and polyradiculitis, although there are also reports of cerebellar ataxia, psychosis, transverse myelitis, ${ }^{10}$ and myositis. ${ }^{11}$ Cerebral infarction $^{12}$ and extrapyramidal features have also been described in mycoplasma related illnesses, and in one instance has been reported as part of an encephalitis lethargica-like illness. ${ }^{13}$ Mycoplasma pneumoniae has been described as a cause of the Guillain-Barré syndrome. ${ }^{14}$ One aspect of our patients which differs from the published reports, however, is the association with respiratory tract infection. In a review of reported patients, ${ }^{7}$ only $21 \%$ did not have an associated chest infection, whereas although the numbers are small, the reverse is true of our patients. In larger studies of acute neurological illness associated with infection, viral causes appear to play a more prominent part. ${ }^{15}$ Our recent experience, however, suggests that $M$ pneumoniae may be responsible for acute neurological illness more often than previously recognised, particularly in the peak years of the epidemic cycle.

Our patients illustrate the diversity of neurological symptoms which may result from infection with $M$ pneumoniae. Although the most common features were seizures and altered consciousness, focal neurological symptoms and bizarre behavioural symptoms were also seen. It should therefore be stressed that the diagnosis of a neurological complication of $M$ pneumoniae infection should be considered in cases of acute encephalopathy and more unusual neurological and neuropsychiatric presentations, even if there is no antecedent respiratory illness.

The diagnosis of $M$ pneumoniae infection rests on serological tests. This led in some of our patients to a delay in diagnosis. It has been suggested by some workers ${ }^{16}$ that the role of mycoplasma infection is coincidental in the pathogenesis of the neurological illness. Certainly the lack of any other means of confirming the diagnosis is a relevant objection when we consider the high prevalence of the infection in the community. Most patients described here, however, also had extensive virological and metabolic investigations, all of which were negative. With the only positive finding being the mycoplasma serology, we therefore feel confident of our diagnoses.

We have taken as our diagnostic criteria a fourfold change in mycoplasma antibodies. This is because investigations were begun well into the course of the illness in many children due to delayed referral; thus we believe that we have caught the serological response decreasing in these patients. We have not relied on IgM responses in particular. Although $\operatorname{IgM}$ is a reliable indicator of recent infection, it is produced less often in reinfection, and thus a negative result does not exclude recent infection, especially in older patients. ${ }^{17}$

The pathogenesis of the disorder is unknown, but there are three suggested 
possibilities. (1) Autoimmune mechanisms: antibodies to brain tissue which cross react with certain complement fixing antibodies to $M$ pneumoniae have been found. ${ }^{18}$ Similar antibodies are found in cases of $M$ pneumoniae infection which do not have any neurological features, however. Thus although perhaps this is the most attractive theory, confirmatory evidence is lacking. (2) Direct neurotoxicity: other species of mycoplasma, such as $M$ neurolyticum, which produces a neurotoxin which affects mice, ${ }^{19}$ and $M$ gallisepticum, which produces cerebral arteritis in turkeys, ${ }^{20}$ have been identified. Similar findings have not been reproduced in studying $M$ pneumoniae. (3) Direct invasion of the cerebrospinal fluid and brain. This remains unproved. There are only two reports of direct invasion of the cerebrospinal fluid in mycoplasma encephalitis, ${ }^{2122}$ despite the large numbers of patients studied.

The uncertainty of the pathogenesis makes treatment difficult. Macrolide antibiotics such as erythromycin remain the drug of choice in mycoplasma infection. Although there is no evidence that they have any effect on the course of mycoplasma induced neurological illness, we might expect an effect if direct invasion was the underlying pathogenetic mechanism. We have taken the view that it is reasonable to use erythromycin if the child is in the acute phase of the illness, particularly if subsequent steroid treatment is contemplated. We have noted the high incidence of vomiting associated with intravenous erythromycin and have tried to use the oral preparation whenever possible, even though this too may cause nausea.

Corticosteroids have been given on the suggestion that there is an immunological basis for the disease. Until recently there has been no published data to show that corticosteroids have a major beneficial effect. A recent report, ${ }^{23}$ however, suggests that high doses of intravenous corticosteroids given in the acute phase of the illness can accelerate recovery. In our two more severely affected patients with central nervous system symptoms, corticosteroids were given by mouth in an attempt to reduce the long term damage, but the overall effect has been difficult to quantify.

The outcome for our patients has been largely one of substantial if not complete recovery; the rapid recovery of some of the patients once recovery has begun, as described by other workers, ${ }^{12}$ is noteworthy. A minority of our patients have been left with major neurological sequelae, but the incidence of this is higher in other reports. ${ }^{24}$

We believe that $M$ pneumoniae infection is not a rare cause of acute neurological illness in childhood, particularly in years of peak incidence in the four year epidemic cycle. It may present in an unusual fashion and should be considered in all acute cases of encephalopathy. The neurological illness may not be preceded by a recognised chest infection. We believe that erythromycin should be given in the acute phase of the illness, but the role of corticosteroids in this disorder remains unproved.

We thank the paediatricians who referred the patients, $\mathrm{Dr} T$ Cox for reporting the radiological investigations, and $\operatorname{Dr} M$ O'Brien for reporting the EEGs.

1 Dalton M. Newton RW. Aseptic meningitis. Dev Med Child Neurol 1991; 33: 446-58.

2 Cassell GH, Cole BC. Mycoplasma as agents of human disease. N Engl f Med 1981; 304: 80-9.

3 Anonymous. Mycoplasma pneumoniae [editorial]. Lancet 1991; 337: 651-2.

4 PHLS. Respiratory tract infections, England and Wales: laboratory reports weeks 90/51-91/02. Communicable Disease Report Weekly 1991; 1 (3): 12, 18 January 1991.

5 PHLS. Respiratory tract infections, England and Wales: laboratory reports weeks 91/51-92/02. Communicable laboratory reports weeks 91/51-92/02. Communicable
Disease Report Weekly 1992; 2 (3): 10-1, 17 January 1992.

6 Ali NJ, Sillis M, Andrews BE, Jenkins PF, Harrison DBW. The clinical spectrum and diagnosis of Mycoplasma pneumoniae infection. $Q \mathcal{F} M e d$ 1986; 227: 241-51.

7 Lerer R, Kavasky SM. Central nervous system disease associated with Mycoplasma pneumoniae infection. Pediatrics 1973; 52: 658-68.

8 Cartensen H, Nilsson K-O. Neurological complications associated with Mycoplasma pneumoniae infection in children. Neuropediatrics 1987; 18: 57-8.

9 Hodges GR, Fass RJ, Saslow S. Central nervous system disease associated with $M$ pneumoniae infection. Arch Intern Med 1972; 130: 277-82.

10 Macfarlane PI, Miller V. Transverse myelitis associated with mycoplasma pneumoniae infection. Arch Dis Child 1984; 59: 80-2.

11 Rothstein TL, Kenny GE. Cranial neuropathy, myeloradiculopathy.and myositis. Complications of Mycoplasma pneumoniae infection. Arch Neurol 1979; 36: 476-7.

12 Parker P, Puck J, Fernandez F. Cerebral infarction associated with Mycoplasma pneumoniae. Pediatrics 1981; 67: 373-5.

13 Al-Mateen M, Gibbs M, Dietrich R, Mitchell WG, Menkes $\mathrm{JH}$. Encephalitis lethargica-like illness in a girl with mycoplasma infection. Neurology 1988; 38: 1155-8.

14 Hodges GR, Perkins RL. Landry-Guillain-Barré syndrome associated with Mycoplasma pneumoniae infection.

15 Kennedy CR, Chrzanowska K, Robinson RO, Tyrell DAJ, Valman HB, Webster ADB. A major role for viruses in acute childhood encephalopathy. Lancet 1986; 327: 989-91.

16 Clyde WA. Neurological syndromes and mycoplasmal infections [editorial]. Arch Neurol 1980; 37: 65-6.

17 Sillis $M$. The limitations of IgM assays in the serological diagnosis of Mycoplasma pneumoniae infections. $\mathcal{f} \mathrm{Med}$ Microbiol 1990; 33: 253-8.

18 Biberfeld G. Antibodies to brain and other tissues in cases of Mycoplasma pneumoniae infection. Clin Exp Immunol 1971; 8: 319-33.

19 Thomas L, Aleu F, Bitensky MW, Davidson M, Gesner B. The neurotoxin of Mycoplasma neurolyticum. $\mathfrak{f} \operatorname{Exp} M e d$ 1966; 124: 1067-82.

20 Thomas L, Davidson M, McCluskey RT. The production of cerebral polyarteritis by Mycoplasma gallisepticum in turkeys: the neurotoxic property of mycoplasma. $\mathcal{f}$ Exp Med 1966; 123: 897-912.

21 Abramovitz P, Schvartzman P, Hare D, Lis I, Naot Y. Direct invasion of the central nervous system by Mycoplasma pneumoniae: a report of two cases. 7 Infect Dis 1987; 155: 482-7.

22 Kasahara I, Otsubo Y, Yanase T, Oshima H, Ichimaru H, Nakamura $M$. Isolation and characterization of Mycoplasma pneumoniae from cerebrospinal fluid of a patient with pneumonia and meningoencephalitis. $\mathcal{f}$ Infect Dis 1985; 152: 823-5.

23 Sheth RD, Goulden KJ. Mycoplasma pneumoniae-associated encephalitis: extension of the clinical spectrum [abstract]. Ann Neurol 1992; 32: 448-9

24 Lehtokoski-Lehtiniemi E, Koskiniemei M-J. Mycoplasma pneumoniae encephalitis: a severe entity in children. Pediatr Infect Dis $\mathcal{F} 1989$; 8: 651-3. 